\title{
Analysis of causative agents of urinary tract infections in children and their antibiotic sensitivity pattern: A hospital based study
}

\author{
*N P Senanayake ${ }^{1}$, N S Chandrasiri ${ }^{2}$ \\ Sri Lanka Journal of Child Health, 2015; 44(4): 197-201
}

\begin{abstract}
Introduction: Urinary tract infections (UTIs) are an important cause of morbidity and mortality in children.

Objective: To determine the common bacterial pathogens causing UTI in children less than 12 years old and their antimicrobial susceptibility patterns at the Colombo South Teaching Hospital, Sri Lanka.
\end{abstract}

Method: A prospective study was done by analyzing records of urine samples received at the Department of Microbiology, Colombo South Teaching Hospital, from $1^{\text {st }}$ May 2011 to $30^{\text {th }}$ April 2012. Urine samples were inoculated on Cystine Lactose Electrolyte Deficient agar, according to standard operating procedures. The isolates were initially identified by Gram staining and colony characteristics. Gram positive organisms were further identified by catalase, coagulase and bile-aesculin tests. Lactose fermentation or non-lactose fermentation (NLF) of Gram negative organisms was recorded. The NLF isolates were further identified by oxidase, urease and Kleigler Iron Agar tests. Antibiotic susceptibility tests were carried out using the Stokes method.

Results: A total of 2620 urine samples was analyzed. Of the $426(16.3 \%)$ pure growths, Gram negative isolates of bacteriuria ( $>10^{5}$ colony forming units $/ \mathrm{ml}$ of urine) and Gram positive isolates of bacteriuria $\left(>10^{4}\right.$ colony forming units $/ \mathrm{ml}$ of urine) were found in $264(62 \%)$ and $56(13.1 \%)$ patients respectively. The female: male ratio of the total positive samples was 2.1:1. LF and NLF Coliforms (excluding Proteus, Providencia, and Morganella spp.) were isolated in $142(33.3 \%)$ and 68 (16\%) samples respectively. Proteus spp. were isolated in $43(10.1 \%)$ samples $38(88.4 \%)$ of which were identified in males. The sensitivity of LF Coliforms to

${ }^{1}$ Lecturer in Microbiology, Faculty of Medicine, General Sir John Kotelawala Defence University, Ratmalana, ${ }^{2}$ Consultant Microbiologist, Department of Microbiology, Colombo South Teaching Hospital, Kalubowila, Sri Lanka

*Correspondence: nilanthisenanayake@yahoo.com Received on 30 September 2014: Accepted after revision on 21 November 2014

The authors declare that there are no conflicts of interest Open Access Article published under the Creative Commons

CC-BY-NC-ND Licence. nitrofurantoin, cephalexin and ampicillin was $83.9 \%$, $57.4 \%$ and $11.3 \%$ respectively. The sensitivity of NLF Coliforms to nitrofurantoin, cephalexin and ampicillin was $85.3 \%, 36.8 \%$ and $7.4 \%$ respectively.

Conclusions: Enterobacteriaceae were the predominant pathogens causing UTI in our population and showed high resistance against ampicillin and cephalexin. Proteus infections were predominant in males.

(Key words: Urinary tract infections, children, causative agents, antibiotic sensitivity pattern)

\section{Introduction}

Urinary tract infection (UTI) is a common health problem during childhood and an important cause of morbidity and mortality in the first 2 years of life ${ }^{1}$. Symptoms of UTI may be minimal and non-specific in infants and small children ${ }^{2}$. Therefore, diagnosis of UTI cannot be made on symptomatology alone and urine examination is advocated in children with minimal suspicion of $\mathrm{UTI}^{3,4}$. UTI may lead to life threatening complications, like septicaemia and renal scarring. Renal scarring is the most common cause of hypertension in later childhood leading to renal failure in adulthood ${ }^{2,5}$. Recognition of UTI in children should be made as early as possible to prevent these complications ${ }^{2}$. Therefore, early diagnosis of UTI is of utmost importance 5 . According to western publications at least $80 \%$ of UTI in children are caused by Escherichia coli followed by organisms like Proteus, Enterococcus, Pseudomonas, Klebsiella, Citrobacter and Staphylococcus species5. Effective antimicrobial therapy for UTI can reduce adverse events in this age group. Most recent studies, particularly in developing countries, on the antimicrobial susceptibility of bacterial pathogens causing UTI in children showed high levels of antibiotic resistance ${ }^{6-9}$. In addition, the prevalence of antimicrobial resistance in young children with UTI is increasing and varies among different geographical and regional locations and various socioeconomic strata ${ }^{10}$. Therefore, it is necessary to identify the bacterial agents responsible for UTI and to determine their sensitivity to antibiotics in our paediatric population.

\section{Objective}

To determine the common bacterial pathogens causing UTI in children less than 12 years old and their 
antimicrobial susceptibility patterns at the Colombo South Teaching Hospital (CSTH), Sri Lanka

\section{Method}

A prospective descriptive study was conducted to find the causative agents of UTI in children and their antibiotic sensitivity pattern by analyzing the records of urine samples received at the Department of Microbiology, CSTH from $1^{\text {st }}$ May 2011 to $30^{\text {th }}$ April 2012. Urine samples received at the Department of Microbiology, from children less than 12 years which have been collected by the midstream or clean catch methods were included in the study. These samples were well mixed and inoculated on Cystine Lactose Electrolyte Deficient (CLED) agar, using calibrated $0.001 \mathrm{ml}(1 \mu \mathrm{l})$ wire loop according to the standard operating procedures. The CLED plates were incubated aerobically at $35^{\circ} \mathrm{C}$ overnight. The isolates were initially identified by Gram staining and colony characteristics. Pure bacterial colony counts of $10^{5}$ or more $\left[\geq 10^{5}\right.$ Colony Forming Units $(\mathrm{CFU}) / \mathrm{ml}$ of urine] was considered as significant for Gram negative isolates and a pure bacterial colony count of $10^{4}$ or more $\left(\geq 10^{4} \mathrm{CFU} / \mathrm{ml}\right.$ of urine) was considered as significant for Gram positive isolates. Gram positive organisms were further identified by catalase, slide/tube coagulase and bile aesculin tests. Lactose fermentation (LF) or non-lactose fermentation (NLF) of Gram negative organisms were recorded. The NLF isolates were further identified by oxidase, urease and Kleigler Iron Agar (KIA) tests.

Antibiotic susceptibility tests were carried out using Stokes method. Antibiotic susceptibility of the Gram negative isolates were tested for the following antibiotics: Ampicillin $(10 \mu \mathrm{g})$, Co-amoxyclav $(20 / 10 \mu \mathrm{g})$, Cephalexin $(30 \mu \mathrm{g})$, Cefuroxime $(30 \mu \mathrm{g})$, Cefotaxime $(30 \mu \mathrm{g})$, Cotrimoxazole $(1.25 / 23.75 \mu \mathrm{g})$, Gentamicin $(10 \mu \mathrm{g})$, Nitrofurantoin $(300 \mu \mathrm{g})$ and Nalidixic acid (30 $\mu \mathrm{g})$. The Cefoxitin (30 $\mu \mathrm{g})$ sensitivity of the

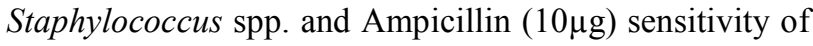
the Streptococcal spp. were also tested.

\section{Results}

A total of 2,620 urine samples was analyzed. Of the 426 $(16.3 \%)$ pure growths Gram negative isolates of bacteriuria ( $>10^{5} \mathrm{CFU} / \mathrm{ml}$ of urine) and Gram positive isolates of bacteriuria $\left(>10^{4} \mathrm{CFU} / \mathrm{ml}\right.$ of urine) were found in $264(62 \%)$ and $56(13.1 \%)$ patients respectively. The female to male ratio of the pure growths was 2.1:1.0.

The distribution of Gram negative urinary tract causative agents is shown in Table 1.

Table 1

Distribution of Gram negative causative agents

\begin{tabular}{|l|c|}
\hline \multicolumn{1}{|c|}{ Bacterial agent } & Number (\%) \\
\hline Lactose Fermenting Coliforms & $142(33.3)$ \\
\hline $\begin{array}{l}\text { Non Lactose Fermenting Coliforms } \\
\text { (excluding Proteus, Providencia, } \\
\text { Morganella } \text { spp.) }\end{array}$ & $68(16.0)$ \\
\hline Proteus spp. & $43(10.1)$ \\
\hline Pseudomonas spp. & $06(01.4$ \\
\hline Acinetobacter spp. & $05(01.2$ \\
\hline
\end{tabular}

Of the 43 Proteus species isolated 38 (88.4\%) were identified in males. All urea positive isolates which could belong to Proteus, Providencia, and Morganella species were reported as Proteus spp. as it is the commonest pathogen of these organisms causing UTIs.

The distribution of Gram positive urinary tract causative agents is shown in Table 2.

Table 2

Distribution of Gram positive causative agents

\begin{tabular}{|l|c|}
\hline \multicolumn{1}{|c|}{ Bacterial agent } & Number (\%) \\
\hline Enterococci spp. & $27(6.3)$ \\
\hline Coagulase negative staphylococci & $19(4.5)$ \\
\hline Staphylococcus aureus & $04(0.9)$ \\
\hline
\end{tabular}

The percentages of the Gram negative isolates that were sensitive to the tested antibiotics are given in Table 3.

Table 3: Percentage sensitivity of the antibiotics to Gram negative organisms

\begin{tabular}{|l|c|c|c|}
\hline \multicolumn{1}{|c|}{ Antibiotic } & LF Coliforms (\%) & NLF Coliforms (\%) & Proteus species (\%) \\
\hline Ampicillin & 11.3 & 7.4 & 23.3 \\
\hline Co-amoxyclav & 66.9 & 54.4 & 58.2 \\
\hline Cephalexin & 57.4 & 36.8 & 53.5 \\
\hline Cefuroxime & 68.3 & 55.8 & 58.2 \\
\hline Cefotaxime & 73.9 & 58.8 & 60.5 \\
\hline Cotrimoxazole & 54.9 & 47.5 & 55.8 \\
\hline Gentamicin & 73.3 & 69.2 & 65.2 \\
\hline Nitrofurantoin & 83.9 & 85.3 & 39.6 \\
\hline Nalidixic acid & 63.4 & 51.5 & 65.2 \\
\hline
\end{tabular}

Of the Gram negative isolates LF and NLF Coliforms (excluding Proteus, Providencia, and Morganella spp.) showed the highest sensitivity to nitrofurantoin, gentamicin, and cefotaxime and the lowest to ampicillin. Proteus species showed the highest sensitivity to nalidixic acid and gentamicin and the lowest sensitivity 
to nitrofurantoin which cannot be used in treatment due to the urea splitting action of Proteus species. Therefore, nitrofurantoin was reported as resistant if the organism was identified as Proteus species irrespective of in vitro sensitivity results. Cefoxitin sensitivity of Staphylococcus aureus and coagulase negative staphylococci were $50 \%$ and $26.3 \%$ respectively. Of the Enterococci species. 63\% were sensitive to ampicillin.

\section{Discussion}

UTIs are of major clinical importance due to high morbidity and mortality rates among children ${ }^{11}$. In the present study, of 2,620 urine samples received at the laboratory, $426(16.3 \%)$ yielded pure growths. In previous studies Enterobacteriaceae was identified as the predominant pathogen in children with UTIs ${ }^{12-13}$. Similar to findings of other studies, the most frequently detected pathogen among children with UTIs in the present study was LF and NLF Coliforms, which belongs to the Enterobacteriaceae group (49.3\%). Of the NLF Coliforms urease test positivity is seen in Proteus, Providencia, and Morganella species. Of these organisms the commonest UTI causing organism is Proteus species. In present study, of the NLF Coliforms urease test positivity was seen in $43(10.1 \%)$ urine isolates. Therefore the urease test positive isolates were most likely to have been Proteus species. Proteus species was isolated in $43(10.1 \%)$ samples and of the Proteus species $38(88.4 \%)$ were identified in males. Previous studies have shown that Proteus species causes more UTIs in males ${ }^{14-16}$. In one study from Turkey Proteus species were isolated only in male patients ${ }^{14}$. This has been explained on the relatively high motility of the Proteus species allowing it to swarm the long urethra of the males and ascend to cause the infection ${ }^{15}$.

In the present study, it was found that among the tested antibiotics, nitrofurantoin, gentamicin and cefotaxime were the most active agents, whereas ampicillin, cephalexin and cotrimoxazole were the least active agents against LF and NLF Coliforms (excluding Proteus spp.). Based on our results, Proteus spp. which mainly caused infections in males showed the highest sensitivity to nalidixic acid and gentamicin. Nitrofurantoin cannot be used in Proteus infections as it is active in acidic urine but due to the ability of Proteus species in splitting urea to release ammonia which in turn makes urine alkaline. When Proteus species were identified nitrofurantoin was reported as resistant irrespective of in vitro sensitivity to avoid treatment failure. According to our results if the laboratory failed to identify Proteus species approximately $40 \%$ of the positive cultures will have Nitrofurantoin reported as sensitive antibiotic leading to treatment failure. Staghorn calculus is more common in males (4:1) in Sri Lanka ${ }^{17}$. Staghorn calculi are associated with Proteus infections and childhood Proteus infections may contribute to the formation of staghorn calculi in adult life. The resistance to antibiotics varies in different societies and in different countries. In general, in poor and underdeveloped countries, the prevalence of antimicrobial resistance is particularly high, which reflects the irrational and excessive use of antimicrobial agents ${ }^{18}$. Therefore monitoring antimicrobial resistance of bacteria causing urinary tract infection is crucial to improve quality of healthcare.

\section{Conclusions}

The present study demonstrated that Enterobacteriaceae, the predominant pathogens causing UTIs in children, show significant resistance to ampicillin and cephalexin. Therefore this higher resistance status should be taken into consideration in the prescription of antibiotics for empirical use or for the development of antibiotic guidelines. This study also showed the importance of identifying Proteus species and reporting nitrofurantoin as resistant in the antibiotic sensitivity report irrespective of in vitro susceptibility status.

\section{References}

1. Jadresi LP. Diagnosis and management of urinary tract infections in children. Paediatrics and Child Health 2010; 20(6): 274-8. http://dx.doi.org/10.1016/j.paed.2010.02.004

2. Chon CH, Lai FC, Shorthffe LM. Paediatric urinary tract infections. Pediatric Clinics of North America. 2001; 48: 1447-59. http://dx.doi.org/10.1016/S00313955(05)703850

3. Srivaths PR, Rath B, Krishna PS, Talukdar B. Usefulness of screening febrile infants for urinary tract infection. Indian Pediatrics 1996; 33: 218-20. PMid: 8772841

4. Chantler C, Berman LH, Jones FC, Gruneberg RN, Haycock GB. Guidelines for the management of acute urinary tract infection in childhood. Journal of Royal College of Physicians of London 1991; 25: 36-41.

5. Watson AR. Disorders of the urinary system. In: Campbell AG, McIntosh N, editors. Forfar and Arneil's Textbook of Pediatrics. New York: Churchill Livingstone 1998; 949-56.

6. Al-Mardeni RI, Batarseh A, Omaish L, Shraideh M, Batarseh B, UnisN. Empirical treatment for paediatric urinary tract infection and resistance patterns of uropathogens, in Queen Alia hospital and Prince A'Isha military center--Jordan. Saudi Journal of Kidney Diseases and Transplantation. 2009; 20(1):135-9.

PMid: 8772841 
7. Al-Mendalawi MD. Antibiotic resistance pattern and empirical therapy for urinary tract infections in children. Saudi Medical Journal. 2008; 29(10): 1520.

PMid: 18946590

8. Anatoliotaki M, Galanakis E, Schinaki A, Stefanaki S, Mavrokosta M, Tsilimigaki A. Antimicrobial resistance of urinary tract pathogens in children in Crete, Greece. Scandinavian Journal of Infectious Diseases. 2007; 39(8): 671-5. http://dx.doi.org/10.1080/00365540701199899

PMid: 17654342

9. Yuksel S, Ozturk B, Kavaz A, Ozcakar ZB, Acar B, Guriz H, et al. Antibiotic resistance of urinary tract pathogens and evaluation of empirical treatment in Turkish children with urinary tract infections. International Journal of Antimicrobial Agents. 2006; 28(5): 413-6.

http://dx.doi.org/10.1016/j.ijantimicag.2006.08.0 09

PMid: 17000085

10. Farrell DJ, Morrissey I, De Rubeis D, Robbins M, Felmingham D. A UK multicenter study of the antimicrobial susceptibility of bacterial pathogens causing urinary tract infection. The Journal of Infection 2003; 46(2): 94-100.

http://dx.doi.org/10.1053/jinf.2002.1091

PMid: 12634070

11. Mortazavi F, Shahin N. Changing patterns in sensitivity of bacterial uropathogens to antibiotics in children. Pakistan Journal of Medical Sciences 2009; 25(5): 801-5.

12. Zhanel GG, Karlowsky JA, Harding GK, Carrie A, Mazzulli T, Low DE, et al. A Canadian national surveillance study of urinary tract isolates from outpatients: comparison of the activities of trimethoprim-sulfamethoxazole, ampicillin, mecillinam, nitrofurantoi and ciprofloxacin. The Canadian Urinary Isolate Study Group. Antimicrobial Agents Chemotherapy 2000; 44(4): 1089-92.

http://dx.doi.org/10.1128/AAC.44.4.10891092.2

000

PMid: 10722520 PMCid: PMC89821
13. Gupta K. Emerging antibiotic resistance in urinary tract pathogens. Infectious Diseases Clinics of North America 2003; 17(2): 243-59. http://dx.doi.org/10.1016/S08915520(03)000060

14. Arslan S, Caksen H, Rastgeldi L, Uner A, Oner AF, Odabas D. Use of urinary gram stain for the detection of urinary tract infection in childhood. Yale Journal of Biology and Medicine. 2002; 75: 73-8.

PMid: 12230312 PMCid: PMC2588732

15. Qureshi AM. Organisms causing urinary tract infection in paediatric patients at Ayub Teaching Hospital Abbottabad. Journal of Ayub Medical College, Abbottabad. 2005; 17(1): 72-4.

PMid: 15929535

16. Habib S. Highlights for management of a child with a urinary tract infection. International Journal of Pediatrics 2012. Available from: http:/www.hindawi.com/journals/ijpedi/2012/9 43653/

17. Abeygunasekera, AM. Urinary stone disease in Sri Lanka. Ceylon Medical Journal. 2004; 49: 41-43. PMid: 15334796

18. Bitsori M, Maraki S, Kalmanti M, Galanakis E. Resistance against broad-spectrum beta-lactams among uropathogens in children. Pediatric Nephrology. 2009; 24(12): 2381-6. http://dx.doi.org/10.1007/s00467-009-1255-1 PMid: 19636594 